\title{
Quality utilization of antenatal care and low birth weight: evidence from 18 demographic health surveys
}

\author{
Saverio Bellizzi and Susanna Padrini²
}

'Partnership for Maternal, Newborn and Child Health, Geneva, Switzerland (Correspondence to: S. Bellizzi: bellizzis@who.int). ${ }^{2}$ Associazione Italiana per la Solidarietà tra i Popoli (AISPO), Milano, Italy.

\begin{abstract}
Background: Low birthweight is a crucial factor in child mortality and morbidity and affects almost $20 \%$ of infants worldwide, mostly in low- and middle-income countries.

Aims: To assess the relationship between access to and quality of antenatal care and occurrence of low birth weight.

Methods: We analysed data from 18 demographic and health surveys, from 2005 to 2013, including 69446 children. The main study outcome was birthweight $<2.5 \mathrm{~kg}$, and access to and number of antematal care visits were exposure variables. Moreover, antenatal care attendants and time of visit (trimester) were considered. Multiple logistic regression adjusted for sampling at primary and country level was utilized.

Results: At least 1 and $\geq 4$ antenatal care consultations were both associated with decreased odds of low birth weight when compared to none and $<4$ antenatal care consultations, respectively. Additional benefit stemmed from having skilled antenatal care attendants and the first antenatal care consultation during the first trimester.

Conclusions: Proper antenatal care coverage during pregnancy is beneficial for preventing low birth weight in low- and middle-income countries.

Keywords: antenatal care, demographic health survey, low birth weight, low-income country, middle-income country

Citation: Bellizzi S; Padrini S. Quality utilization of antenatal care and low birth weight: evidence from 18 demographic health surveys. East Mediterr Health J. 2020;26(11):1381-1387. https://doi.org/10.26719/emhj.20.055

Received: 14/11/18; accepted: 24/11/19

Copyright (c) World Health Organization (WHO) 2020. Open Access. Some rights reserved. This work is available under the CC BY-NC-SA 3.0 IGO

license (https://creativecommons.org/licenses/by-nc-sa/3.o/igo)
\end{abstract}

\section{Introduction}

In 2012, the World Health Assembly endorsed a comprehensive plan under Resolution 65.6 with specific global nutrition targets for 2025 (1). This policy included a 30\% reduction in low birthweight (LBW) (2), corresponding to a reduction from 20 million to $\sim 14$ million neonates with birthweight $<2.5 \mathrm{~kg}$ (3) between 2012 and 2025 . LBW affects almost one sixth of infants worldwide with $>95 \%$ of cases located in developing countries (3), and is recognized as 1 of the most influential factors on child mortality and morbidity. LBW increases mortality risk by $20-30$ times (4), and contributes to $60-80 \%$ of all neonatal deaths worldwide $(5,6)$. Surviving infants are at higher risk of pathological conditions such as infection immediately after birth and throughout the first year of life (7). LBW is also associated with morbidity later in life, such as psychosocial disorders (8), impaired cognitive function (9), coronary heart disease (10) and noninsulin dependent diabetes (11). Several risk factors are claimed to be associated with LBW, including maternal factors, pregnancy, multiple gestation, socioeconomic characteristics, drug treatment and body mass index (12-15).

At least 4 antenatal care (ANC) consultations, with the first preferably in the first trimester (16), has been a worldwide recommended policy for the last 2 decades. However, there is still inconclusive evidence on its impact on maternal and neonatal outcomes in developing countries. Some studies have shown that ANC improves birthweight $(17,18)$, while others have shown a lack of evidence for the effectiveness of content, frequency and timing of visits in standard ANC programmes on maternal and child health (19).

Our research used data from demographic and health surveys (DHSs) in 18 countries and examined the association between adequate utilization of ANC and occurrence of LBW.

\section{Methods}

\section{Study design}

This was a population-based study of data from 18 DHSs between 2005 and 2013, which reported birthweight for at least $80 \%$ of births over the 5 years preceding the survey: Albania 2008/2009, Armenia 2010, Congo (Brazzaville) 2011/2012, Dominican Republic 2013, Gabon 2012, Guyana 2009, Honduras 2011/2012, Indonesia 2012, Jordan 2012, Kyrgyzstan 2012, Maldives 2009, Republic of Moldova 2005, Peru 2012, Philippines 2013, Sao Tome and Principe 2008/2009, Swaziland 2006/07, Tajikistan 2012, and Ukraine 2007. Detailed information on procedures and sampling techniques for all DHSs have been published elsewhere (20). Face-to-face interviews were carried out for a total of 213752 women. 


\section{Study population}

The study population consisted of all the latest singleton live births ( $n=77809)$ during the 5 years preceding the DHS in each country. After excluding 8363 (10.7\%) individuals for whom we had missing data on BW, the final sample included 69446 babies. Information on BW was obtained through birth certificates and maternal recall for $21334(30.7 \%)$ and $48112(69.3 \%)$ infants, respectively.

\section{Outcome, exposure and control variables}

The main outcome was LBW, which was defined as $<2.5$ $\mathrm{kg}$. Characteristics of ANC were the exposure variables, which were defined as follows: "ANC", if any ANC consultation was performed; "provider", classified as skilled (doctors, nurses or other trained attendants) or unskilled attendant (traditional attendants or others); "number of ANC consultations", subdivided into $<4$ or $\geq 4$ ANC visits; "ANC timing", dichotomized into ANC first consultation in the first trimester or after the first trimester; and "quality of ANC", with $\geq 4$ ANC consultations started in the first trimester with a skilled attendant on 1 side, and all the others on the other side. A series of socioeconomic, pregnancy and maternal characteristics were evaluated as possible confounders, including age, education, wealth, place of residence, birth interval, birth order, wanted pregnancy and child sex.

\section{Statistical analysis}

Statistical analysis was performed using STATA 13.1 SE (StataCorp, College Station, TX, USA). The "svy" command was used to adjust for clustering by primary sampling unit. Number of total livebirths and LBW by country were tabulated with relative percentages. All the study categorical confounding variables were tested against LBW using the $\chi^{2}$ test. Furthermore, we used the $\chi^{2}$ test to examine the association between the quality of ANC and the following socioeconomic variables: wealth status, maternal age and education, and place of residence.

The Metaprop syntax (21) was used in the pooled meta-analysis of all country datasets, which generated weighted subgroup and overall pooled estimates with inverse-variance weights obtained from a random-effects model. In this model, no residual heterogeneity was assumed. The final model included wealth, age, birth order, birth spacing, education, wanted pregnancy, child sex, and rural/urban residence; the factors primary sampling unit and country were added with random effect. Stepwise logistic regression analysis of LBW on the 5 ANC exposure variables was conducted adjusting for socioeconomic, maternal and pregnancy characteristics. $P<0.05$ was considered statistically significant.

\section{Ethical approval}

This study used existing data obtained from ORC Macro (Calverton, MD, USA) through formal request mechanisms (https://dhsprogram.com). No additional ethical review for the secondary analysis was required since each country and the Institutional Review Board of ORC Macro approved the DHS data collection procedures.

\section{Results}

Overall, 6238 (9.0\%) newborns with LBW were recorded, ranging from a minimum of $36(2.8 \%)$ of 1281 in Albania to a maximum of $883(20.8 \%)$ of 4238 newborns in the Philippines (Table 1). Data on ANC were missing for 1404 individuals, corresponding to $2 \%$ of the total study population. Most mothers had ANC ( $n=66513 ; 97.7 \%)$ and half of them $(n=33038)$ had the first consultation during the first trimester (Table 2). Only 6517 (10\%) women had $<4$ consultations. Almost all pregnant women $(97.2 \%)$ consulted a trained operator. Less than half of them $(n=31372)$ had a good quality of ANC according to World Health Organization (WHO) criteria.

Table 3 shows a clear trend toward increasing prevalence of LBW with decreasing wealth, poorer education and shorter birth intervals, in addition to higher risk in unwanted pregnancies and female sex.

There were associations between wealth status and education and the quality of ANC. The richest and most educated women, in addition to those living in urban areas, were more likely to have $\geq 4$ ANC consultations performed by skilled attendants, with the first consultation during the first trimester.

The adjusted logistic regression showed a significant benefit of having any ANC consultation when compared

Table 1 Numbers of live births and low birth weight infants in 18 low- and middle-income countries

\begin{tabular}{lcc} 
Country, year & Live births & $\begin{array}{c}\text { Low birth } \\
\text { weight (\%) }\end{array}$ \\
\hline Albania 2008/2009 & 1281 & $36(2.8)$ \\
Armenia 2010 & 1139 & $1,438(6.0)$ \\
Congo (Brazzaville 2011/2012) & 5355 & $467(8.7)$ \\
Dominican Republic 2013 & 2847 & $378(13.3)$ \\
Gabon 2012 & 3485 & $445(12.8)$ \\
Guyana 2009 & 1294 & $167(12.9)$ \\
Honduras 2011/2012 & 7062 & $654(9.3)$ \\
Indonesia 2012 & 13045 & $840(6.4)$ \\
Jordan 2012 & 6612 & $817(12.4)$ \\
Kyrgyzstan 2012 & 3089 & $147(4.8)$ \\
Maldives 2009 & 3206 & $328(10.2)$ \\
Republic of Moldova 2005 & 1350 & $63(4.7)$ \\
Peru 2012 & 7385 & $479(6.5)$ \\
Philippines 2013 & 4238 & $883(20.8)$ \\
Sao Tome and Principe 2008/2009 & 1159 & $79(6.8)$ \\
Swaziland 2006/2007 & 1788 & $116(6.5)$ \\
Tajikistan 2012 & 2955 & $197(6.7)$ \\
Ukraine 2007 & 2156 & $74(3.4)$ \\
Total & 69446 & $6238(9.0)$ \\
\hline
\end{tabular}

Results are total number of newborns and number of low birthweight infants among the last births for each woman in the preceding 5 years. Results from 18 demographic health surveys. 


\begin{tabular}{|c|c|c|c|c|c|}
\hline \multirow[t]{2}{*}{ ANC variables } & \multicolumn{2}{|c|}{ Low birth weight } & \multicolumn{2}{|c|}{ Normal weight } & \multirow{2}{*}{$\begin{array}{l}P \\
\chi^{2}\end{array}$} \\
\hline & $\mathbf{n}$ & (\%) & n & $(\%)$ & \\
\hline \multicolumn{6}{|l|}{ ANC } \\
\hline No & 177 & (11.6) & 1,352 & $(88.4)$ & \multirow[t]{2}{*}{$<0.001$} \\
\hline Yes & 5948 & $(8.9)$ & 60565 & (91.1) & \\
\hline \multicolumn{6}{|c|}{ Time of first ANC consultation } \\
\hline First trimester & 2795 & $(8.5)$ & 30243 & (91.5) & \multirow[t]{2}{*}{$<0.001$} \\
\hline After first trimester & 3248 & $(9.4)$ & 31406 & (90.6) & \\
\hline \multicolumn{6}{|l|}{ No. of ANC consultations } \\
\hline$\geq 4$ & 5108 & $(8.5)$ & 54888 & (91.5) & \multirow[t]{2}{*}{$<0.001$} \\
\hline$<4$ & 840 & $(12.9)$ & 5677 & $(87.1)$ & \\
\hline \multicolumn{6}{|l|}{ ANC attendant } \\
\hline Skilled & 5908 & (8.9) & 60291 & (91.1) & \multirow[t]{2}{*}{$<0.001$} \\
\hline Unskilled & 217 & (11.8) & 1626 & $(88.2)$ & \\
\hline \multicolumn{6}{|l|}{ ANC highest quality } \\
\hline Yes & 2628 & $(8.4)$ & 28744 & (91.6) & \multirow[t]{2}{*}{$<0.001$} \\
\hline No & 3610 & (9.5) & 34464 & $(90.5)$ & \\
\hline
\end{tabular}

to no ANC (OR 1.2; 95\% CI 1.0-1.4) (Table 4). Among infants of women who underwent ANC, having < 4 consultations, first consultation after the first trimester, being attended by an unskilled operator and not meeting WHO quality criteria were associated with 1.5 (95\% CI 1.4-1.7), 1.1 (95\% CI 1.0-1.2), 1.2 (95\% CI 1.1-1.4) and 1.1 (95\% CI 1.0-1.2) increased ORs of LBW, respectively.

\section{Discussion}

This secondary analysis of DHS data from 18 countries showed that the absence of ANC consultation increased the risk of LBW. All WHO criteria, separately and combined, for adequate antenatal consultations resulted in significant protection against LBW. We compared our results on the country incidence of LBW with other sources and found no substantial differences. Estimates from the United Nations Children's Fund and WHO global and country reports on LBW confirm the smallest percentage (3\%) for Albania up to the highest $(20 \%)$ in the Philippines (22).

Our findings on the influence of maternal education on LBW are not surprising. A study in the Islamic Republic of Iran showed that the prevalence of LBW in infants born to women with no education was $16.9 \%$, which decreased to $5.4 \%$ in women educated to a higher level (23). The explanation may lie in greater access to ANC and better nutritional behaviour. Similarly, parity and birth spacing have been detected as important determinants for LBW. One study showed that mothers with very short interpregnancy intervals (IPIs; < 3 months) and high parity had a higher risk of having LBW infants when compared to those with very short IPI but low parity (24). The explanation for these differences may be depleted nutritional reserves in women with high parity and short IPI.

Other DHSs from single countries have reported the benefit of an early start to ANC and the importance of a sufficient number of consultations. A study from Nepal showed how women with no ANC were twice as likely to have LBW infants when compared to mothers with $\geq 4$ ANC consultations (25). A study from Colombia reported that having the first ANC after the first trimester was associated with an increased OR for LBW when compared with first visits at the first trimester (26). Similar findings were reported in a study in Kenya (27), indicating a positive effect of ANC, which influences dietary behaviour and treatment from any illness that may have negative effects on the health of the fetus.

Although our secondary analysis had advantages, such as large sample size and use of standardized questionnaires that limited the risk of intercountry variation, it had some limitations. First, we considered only the 18 DHSs with at least $80 \%$ of data on BW, but we cannot exclude bias for all remaining women not able to report information, which may have led to underestimation of LBW. Second, two thirds of the information on BW relied on maternal recall, therefore presenting a particular type of misreporting called heaping. Heaping consists of rounding and reporting weights as multiple of $500 \mathrm{~g}$, which makes interpretation difficult when infants are reported as weighing $2.5 \mathrm{~kg}$, and thus likely to be misclassified as having normal weight (28). Third, several possible confounding variables such as genetics and maternal history of diseases were not available. Finally, we had no information on nutritional status of women to exclude maternal factors that would increase risk of LBW. 


\begin{tabular}{|c|c|c|c|c|c|}
\hline \multirow[t]{2}{*}{ Maternal characteristics } & \multicolumn{2}{|c|}{ Low birth weight } & \multicolumn{2}{|c|}{ Normal weight } & \multirow{2}{*}{$\begin{array}{c}P \\
\chi^{2}\end{array}$} \\
\hline & $\mathbf{n}$ & (\%) & n & (\%) & \\
\hline \multicolumn{6}{|l|}{ Maternal age (years) } \\
\hline $15-19$ & 568 & $(13.2)$ & 3745 & $(86.8)$ & \multirow[t]{7}{*}{$<0.001$} \\
\hline $20-24$ & 1541 & $(9.7)$ & 14305 & $(90.3)$ & \\
\hline $25-29$ & 1538 & $(8.1)$ & 17383 & (91.9) & \\
\hline $30-34$ & 1155 & $(7.7)$ & 13756 & $(92.2)$ & \\
\hline $35-39$ & 838 & $(8.5)$ & 8996 & (91.5) & \\
\hline $40-44$ & 479 & $(10.4)$ & 4127 & $(89.6)$ & \\
\hline $45-49$ & 119 & (11.7) & 896 & $(88.3)$ & \\
\hline \multicolumn{6}{|l|}{ Birth order } \\
\hline 1 & 2,227 & $(10.6)$ & 19920 & $(89.9)$ & \multirow[t]{2}{*}{$<0.001$} \\
\hline$>1$ & 4,011 & (8.5) & 43288 & (91.5) & \\
\hline \multicolumn{6}{|c|}{ Preceding birth interval (months) } \\
\hline$<18$ & 397 & $(12.1)$ & 2871 & $(87.8)$ & \multirow[t]{4}{*}{$<0.001$} \\
\hline $18-23$ & 438 & $(9.2)$ & 4337 & $(90.8)$ & \\
\hline $24-35$ & 863 & $(8.4)$ & 9347 & (91.5) & \\
\hline$>35$ & 2313 & (8.0) & 26733 & $(92.0)$ & \\
\hline \multicolumn{6}{|l|}{ Place of residence } \\
\hline Urban & 2936 & (8.7) & 30829 & (91.3) & \multirow[t]{2}{*}{0.01} \\
\hline Rural & 3302 & $(9.2)$ & 32379 & $(90.7)$ & \\
\hline \multicolumn{6}{|l|}{ Education } \\
\hline No education & 248 & $(11.7)$ & 1869 & $(88.3)$ & \multirow[t]{4}{*}{$<0.001$} \\
\hline Primary & 1901 & $(10.1)$ & 16897 & $(89.9)$ & \\
\hline Secondary & 3094 & (8.7) & 32338 & (91.3) & \\
\hline Higher & 992 & $(7.6)$ & 12063 & $(92.4)$ & \\
\hline \multicolumn{6}{|l|}{ Wealth index } \\
\hline Poorest & 1882 & (11.3) & 14780 & $(88.7)$ & \multirow[t]{5}{*}{$<0.001$} \\
\hline Poorer & 1540 & (9.4) & 14748 & $(90.5)$ & \\
\hline Middle & 1202 & (8.5) & 13009 & (91.5) & \\
\hline Richer & 960 & $(7.8)$ & 11378 & $(92.2)$ & \\
\hline Richest & 654 & (6.6) & 9293 & (93.4) & \\
\hline \multicolumn{6}{|l|}{ Wanted pregnancy } \\
\hline Wanted & 4077 & (8.5) & 44109 & (91.5) & \multirow[t]{2}{*}{$<0.001$} \\
\hline Not wanted & 2156 & $(10.2)$ & 19057 & $(89.8)$ & \\
\hline \multicolumn{6}{|l|}{ Child sex } \\
\hline Male & 2964 & $(8.2)$ & 33031 & (91.8) & \multirow[t]{2}{*}{$<0.001$} \\
\hline Female & 3274 & (9.8) & 30177 & (90.2) & \\
\hline
\end{tabular}

In conclusion, our study reinforces the need to encourage pregnant women to attend ANC to reduce LBW, with its short- and long-term consequences. Policies should in particular address access to and quality of ANC among disadvantaged socioeconomic groups, which are at higher risk of LBW. Uneducated mothers are less likely to understand health messages and to be concerned about their health and nutritional status. Poorer women are less likely to afford the cost of ANC and transportation in areas where health infrastructure is distant.

Funding: None.

Competing interests: None declared. 


\begin{tabular}{|c|c|c|}
\hline ANC & OR (95\% CI) unadjusted & OR (95\% CI) adjusted ${ }^{\mathrm{a}}$ \\
\hline No ANC visit & $1.3(1.1-1.6)$ & $1.2(1.0-1.4)$ \\
\hline$<4$ ANC visits & $1.6(1.5-1.7)$ & $1.5(1.4-1.7)$ \\
\hline ANC visit after first trimester & $1.1(1.0-1.2)$ & $1.1(1.0-1.2)$ \\
\hline No Skilled ANC & $1.4(1.2-1.6)$ & $1.2(1.1-1.4)$ \\
\hline No Quality ANC & $1.1(1.0-1.2)$ & $1.1(1.0-1.2)$ \\
\hline
\end{tabular}

${ }^{a}$ Adjustedforwealth, age, birth order, birth spacing, education, wanted pregnancy, child sex, and rural/urban residence.

$\mathrm{ANC}=$ antenatal care $\mathrm{CI}=$ confidence interval; $\mathrm{OR}=$ odds ratio.

\section{Utilisation qualitative des soins prénatals et faible poids de naissance : données issues de 18 enquêtes démographiques sur la santé \\ Résumé}

Contexte : Le faible poids à la naissance est un facteur crucial de la mortalité et de la morbidité infantiles et touche près de $20 \%$ des nourrissons dans le monde, principalement dans les pays à revenu faible et intermédiaire.

Objectifs : La présente étude avait pour objet d'évaluer le lien entre l'accès aux soins prénatals et leur qualité d'une part, et le faible poids de naissance d'autre part.

Méthodes : Nous avons analysé les données de 18 enquêtes démographiques et sanitaires, de 2005 à 2013 , portant sur 69446 enfants. Le principal résultat de l'étude concernait un poids de naissance inférieur à 2,5 kg. L'accès aux visites prénatales et le nombre de consultations étaient des variables d'exposition. En outre, le personnel de consultation prénatale et le calendrier des visites (trimestrielles) ont été pris en compte. La régression logistique multiple ajustée pour l'échantillonnage aux niveaux primaire et national a été utilisée.

Résultats : Deux facteurs, en l'occurrence le fait d'avoir au moins une consultation prénatale et un nombre de visites supérieur ou égal à quatre, ont été associés à une diminution de la probabilité de faible poids de naissance par rapport à l'absence de visite et à un nombre de consultations prénatales inférieur à quatre, respectivement. La mise à disposition de personnel de consultation prénatale qualifié et la première consultation prénatale prévue au cours du premier trimestre de la grossesse constituaient également des avantages.

Conclusions: Une couverture adéquate des soins prénatals pendant la grossesse est bénéfique pour prévenir le faible poids de naissance dans les pays à revenu faible et intermédiaire.

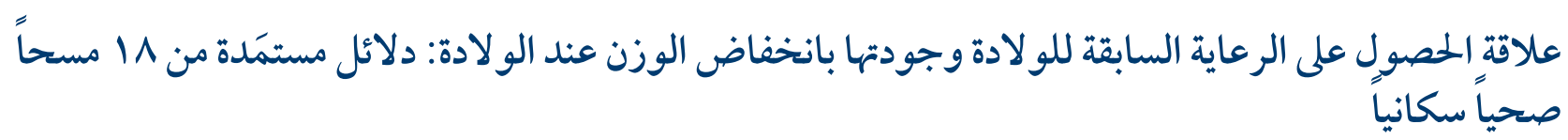
سافيريو بيليزي، سوزانا بادريني

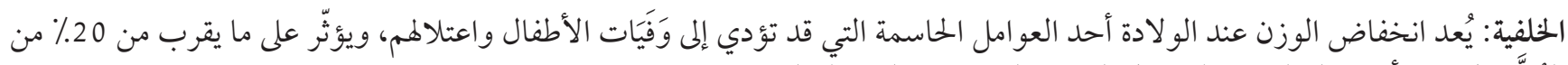

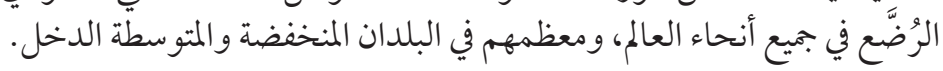
الأهداف: هدفت هذه الدراسة إلى تقييم العلاقة بين الخصول على الرعاية السابقة للو لادة وجودتها وانخفاض الوزن عند الو لادة.

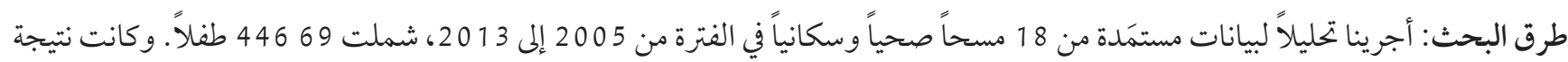

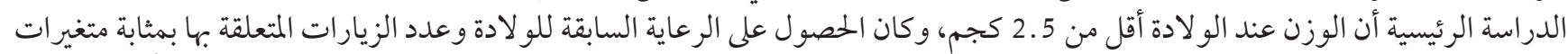

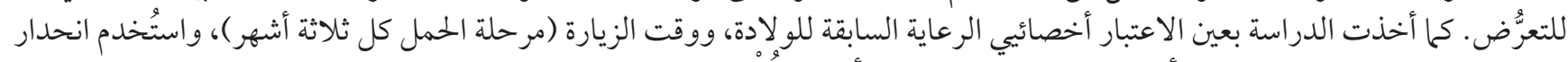

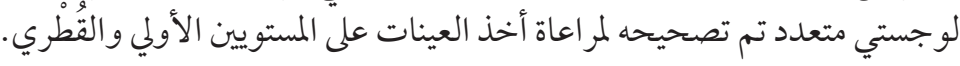

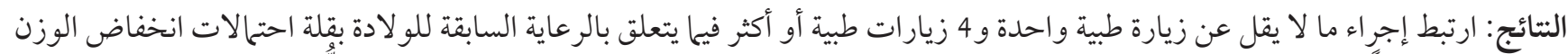

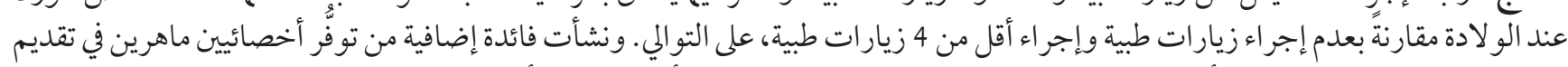

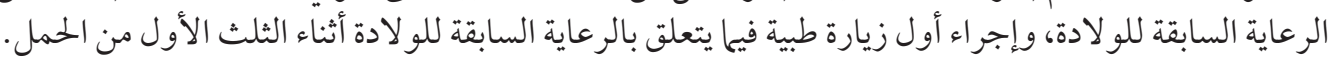

الاستنتاجات: التغطية المناسبة بالرعاية السابقة للو لادة أثناء الحمل مفيدة للوقاية من انخفاض الوزن عند الولادة في البلدان المنخفضة والمتوسطة الدخل. 


\section{References}

1. Comprehensive implementation plan on maternal, infant and young child nutrition. WHA 65/6. Geneva: World Health Organization; 2012 (https://www.who.int/nutrition/publications/CIP_document/en/, accessed 6 May 2020).

2. Global targets 2025. To improve maternal, infant and young child nutrition. Geneva: World Health Organization. (https://www. who.int/nutrition/global-target-2025/en/, accessed 6 May 2020).

3. Guidelines on Optimal feeding of low birthweight infants in low- and middle-income countries. Geneva: World Health Organization; 2011 (https://www.who.int/maternal_child_adolescent/documents/infant_feeding_low_bw/en/, accessed 6 May 2020).

4. Romero C, Duke J, Dabelea D, Romero T, Ogden LG. Does the epidemiologic paradox hold in the presence of risk factors for low birth weight infants among Mexican-born women in Colorado? J Health Care Poor Underserved. 2012 May;23(2):604-14. http:// dx.doi.org/10.1353/hpu.2012.0065 PMID:22643610

5. Care of the preterm and/or low-birth-weight newborn. World Prematurity Day - 17 November 2018 [website]. World Health Organization (http://www.who.int/maternal_child_adolescent/newborns/prematurity/en/, accessed 6 May 2020).

6. Lawn J, Blencowe H, Oza S, You D, Lee AC, Waiswa P, et al. Every newborn: progress, priorities, and potential beyond survival. Lancet. 2014 Jul 12;384(9938):189-205. http://dx.doi.org/10.1016/So140-6736(14)60496-7 PMID:24853593

7. Varga P, Berecz B, Gasparics A, Dombi Z, Varga Z, Jeager J, et al. Morbidity and mortality trends in very-very low birth weight premature infants in light of recent changes in obstetric care. Eur J Gynecol Reprod Biol. 2017 Apr;211:134-9. http://dx.doi. org/10.1016/j.ejogrb.2017.01.051 PMID:28258032

8. Nomura Y, Wickramaatne PJ, Pilowsky DJ, Newcorn JH, Bruder-Costello B, Davey C, et al. Low birthweight and risk of affective disorders \& selected medical illness in offspring at high and low risk for depression. Compr Psychiatry. 2007 Sep-Oct;48(5):4708. http://dx.doi.org/10.1016/j.comppsych.2007.04.005 PMID:17707257

9. Farajdokht F, Sadigh-Eteghad S, Dehghani R, Mohaddes G, Abedi L, Bughchechi R, et al. Very low birth weight is associated with brain structure abnormalities and cognitive function impairments: a systematic review. Brain Cogn. 2017 Nov;118:80-9. http:// dx.doi.org/10.1016/j.bandc.2017.07.006 PMID:28802183

10. Wang SF, Shu L, Sheng J, Mu M, Wang S, Tao XY, et al. Birth weight and risk of coronary heart disease in adults: a meta-analysis of prospective cohort studies. J Dev Orig Health Dis. 2014 Dec;5(6):408-19. http://dx.doi.org/10.1017/S2040174414000440 PMID:25263759

11. Ova J, Nakagami T, Kurita M, Yamamoto Y, Hasegawa Y, Tanaka Y, et al. Association of birthweight with diabetes and insulin sensitivity or secretion in the Japanese general population. J Diabetes Investig. 2015 Jul;6(4):430-5. http://dx.doi.org/10.1111/ jdi.12325 PMID:26221521

12. Gao W, Paterson J, Carter S, Percival T. Risk factors for preterm and small-for-gestational-age babies: a cohort from the Pacific Islands Families Study. J Paediatr Child Health. 2006 Dec;42(12):785-92. http://dx.doi.org/10.1111/j.1440-1754.2006.00978.x PMID:17096714

13. Nguyen N, Savitz DA, Thorp JM. Risk factors for preterm birth in Vietnam. Int J Gynaecol Obstet. 2004 Jul;86(1):70-8. http:// dx.doi.org/10.1016/j.ijgo.2004.04.003 PMID:15207686

14. Sebayang SK, Dibley MJ, Kelly PJ, Shankar AV, Shankar AH; SUMMIT Study Group. Determinants of low birthweight, small-forgestational-age and preterm birth in Lombok, Indonesia: analysis of the birthweight cohort of the SUMMIT trial. Trop Med Int Health. 2012 Aug;17(8):938-50. http://dx.doi.org/10.1111/j.1365-3156.2012.03039.x PMID:22943372

15. Mpharm SA, Hababeh M, Kitamura A, Hajat S. Factors associated with low birthweight in Palestinian refugees at Al-Wehdat camp, Jordan: a cross-sectional study using routine data. Lancet. 2019;393(S8). https://doi.org/10.1016/So140-6736(19)30594-X

16. Provision of effective antenatal care: integrated management of pregnancy and child birth (IMPAC). Standards for maternal and neonatal care (1.6), Department of Making Pregnancy Safer, World Health Organization; 2006 (https://www.who.int/reproductivehealth/publications/maternal_perinatal_health/effective_antenatal_care.pdf, accessed 6 May 2020).

17. Nazim NH, Fan L. Does prenatal healthcare improve child birth weight outcomes in Azerbaijan? Results of the national demographic and health survey. Econ Hum Biol. 2011 Jan;9(1):56-65. http://dx.doi.org/10.1016/j.ehb.2010.08.003 PMID:20851064

18. Jewell RT, Triunfo P. The impact of prenatal care on birth weight: the case of Uruguay. Health Econ. 2006 Nov;15(11):1245-50. http://dx.doi.org/10.1002/hec.1121 PMID:16786548

19. Reichman NE, Corman H, Noonan K, Dave D. Infant health production functions: what a difference the data make. Health Econ. 2009 Jul;18(7):761-82. http://dx.doi.org/10.1002/hec.1402 PMID:18792077

20. The DHS Program. Demographic and health surveys [website] (Dhsprogram.com/publications/index.cfm, accessed 6 May 2020).

21. Nyaga VN, Arbyn M, Aerts M. Metaprop: a Stata command to perform meta-analysis of binomial data. Arch Public Health. 2014 Nov 10;72(1):39. http://dx.doi.org/10.1186/2049-3258-72-39 PMID:25810908

22. Low birthweight: country, regional and global estimates. New York: United Nations Children's Fund and World Health Organization; 2004 (http://www.who.int/iris/bitstream/10665/43184/1/9280638327.pdf, accessed 6 May 2020).

23. F. Jafari, H. Eftekhar, A. Pourreza, J. Mousavi. Socio-economic and medical determinants of low birth weight in Iran: 20 years after establishment of a primary healthcare network. Public Health. 2010 Mar;124(3):153-8. http://dx.doi.org/10.1016/j. puhe.2010.02.003 PMID:20226486 
24. Merklinger-Gruchala A, Jasienska G, Kapiszewska M. Short interpregnancy interval and low birth weight: A role of parity. Am J Hum Biol. 2015 Sep-Oct;27(5):660-6. http://dx.doi.org/10.1002/ajhb.22708 PMID:25754897

25. Khanal V, Zhao Y, Sauer K. Role of antenatal care and iron supplementation during pregnancy in preventing low birth weight in Nepal: comparison of national surveys 2006 and 2011. Arch Public Health 2014 Feb;72(1):4. http://dx.doi.org/10.1186/2049-3258-724 PMID:24499636

26. Pinzon-Rondon AM, Gutierrez-Pinzon V, Madrinan-Navia H, Amin J, Aguilera-Otalvaro P, Hoyos-Martínez A. Low birth weight and prenatal care in Colombia: a cross-sectional study. BMC Pregnancy Childbirth. 2015 May 20;15:118. http://dx.doi.org/10.1186/ s12884-015-0541-0 PMID:25989797

27. Awiti JO. A multilevel analysis of prenatal care and birth weight in Kenya. Health Econ Rev 2014 Dec;4(1):33. http://dx.doi. org/10.1186/s13561-014-0033-3 PMID:26208933

28. Blanc AK, Wardlaw T. Monitoring low birth weight: an evaluation of international estimates and an updated estimation procedure. Bull World Health Organ. 2005 Mar;83(3):178-85. http://dx.doi.org/So042-96862005000300010 PMID:15798841 